Nr 2(65), 2020, s. 239-256

https://doi.org/10.12797/Politeja.17.2020.65.17

\author{
George CASSAR \\ University of Malta \\ george.cassar@um.edu.mt \\ Marie AVELLINO (D) \\ University of Malta \\ marie.avellino@um.edu.mt
}

\title{
NEGOTIATING A POSTMEMORY \\ DICHOTOMY: NOSTALGIA \\ AND AVERSION IN MALTA
}

ABSTRACT The island of Malta has served as a strategic colony since the dawn of history. Since Phoenician and Roman times, the island has been an important base in the middle of the Mediterranean Sea. Its last colonisers, the British, spent about 180 years using the islands for their imperial needs. The official closing of the British base on 31 March 1979 heralded a new economic and social reality supposedly unhampered by the exigencies of foreigners. Two major post-memory reactions kicked in - nostalgia and aversion to ex-colonial life. The postcolonial Maltese generations exhibit a range of reactions oscillating between love and hate for the British. On the other hand, British ex-service personnel and their families have continued to feel an affinity with the island base which they had come to acknowledge as a second home. This allows for a new type of relationship between the Maltese people and their British visitors where issues of colonial post-memory are negotiated. These are seen at their best in the local tourism industry. Malta woos British tourists and goes to great effort to attract them. It uses to its advantage the colonial affinity to create an attractive destination for the British which benefits the locals and the Maltese economy. In Malta post-memory has evolved in line with necessity and expediency, where animosity, though manifestly tangible, has gradually morphed into a rather benign residue in the collective reaction to the colonial past.

Keywords: Malta, British colony, tourism industry, nostalgia, colonial aversion 


\begin{abstract}
A colonial experience is, in the majority of times, an ordeal through which the colonised have to endure the whims and pleasures of the coloniser. The local population is held hostage by its historical and circumstantial destiny. It has to steer through domination and suppression as best it can, dealing with conditions which are largely out of its control, and to futures that are typically contrasting to its desires. Correlationally, the ordeal borne by the locals tends to become more cumbersome and at times quite traumatic the longer the colonial presence endures. Malta's colonial past stretches back to whole millennia; indeed, thousands of years of servitude and submission which shaped the locals' national memory and are reflected in the people's negotiation of post-memory.
\end{abstract}

\title{
RATIONALE AND METHODOLOGY
}

The aim of this exploratory research paper is to gain an understanding of the present relationship between the Maltese and the British after the Maltese Islands gained independence from Britain and now serve as a major tourist destination for the ex-colonisers. It is useful to understand this relationship which carries with it the tensions between the colonised and the ex-colonials, now transmuted into guests and hosts through tourism. To understand this relationship, this study focuses on how the cultural broker mediates between hosts and guests as 'others' and it explores the strategies taken by the brokers, along with many of the local residents, to nullify the negative post-memories of the British colonial presence as it seeks to attract more British tourists to the islands.

The research was undertaken by using secondary sources such as brochures, archival documents and other pertinent literature. It was also supported by primary sources such as interviews with locals, tourist guides and other cultural brokers. Furthermore, ethnographic research was carried out by one of the present authors who interviewed both British tourists and Maltese nationals over a period of ten years. ${ }^{1}$

\section{LITERATURE REVIEW}

Cultural brokering is the act of bridging, linking or mediating between groups or persons of differing cultural backgrounds for the purpose of reducing conflict or producing change. ${ }^{2}$ Cultural brokers straddle two or more different cultures through interpretation and do this by transmitting meanings or messages between one culture and

\footnotetext{
M. Avellino, The Maltese Gift: Tourist Encounters with the Self and the Other in Later Life, unpublished Ph.D. thesis, London Metropolitan University, 2016, at <http://ethos.bl.uk/OrderDetails. do?uin=uk.bl.ethos.694191>, 10 February 2020.

2 M.A. Jezewski, P. Sotnik, The Rehabilitation Service Provider as Culture Broker: Providing Culturally Competent Services to Foreign Born Persons, Buffalo, NY 2001.
} 
another, usually with the aim of fostering understanding and mitigating conflict. The final aim of the mediator is usually for the recipient to 'act,' culminating in some form of economic transaction, usually with the aim of fostering understanding and mitigating conflict or producing change. ${ }^{3}$

Cultural brokers - hosts and guests - tell stories, narratives. They do so before the visit, during and also afterwards. In the case of the pre-tour narratives such as those found in marketing material, brochures, and guidebooks, these are pre-understandings. In a study of Bali, Bruner contends that 'master narratives have tremendous consequences' while they create meaning, shape action, form tourist behaviour, create an opportunity for selecting which aspects of the destination's culture will be presented to tourists, steer towards the construction of an infrastructure for those coming from outside, and operate in covert ways, at times on the unconscious level. Bruner found that the prosaic side of the life of his case-study destination was omitted and instead the focus fell on what aspects of the culture were perceived to be of interest to foreigners. ${ }^{4}$ This paper proposes that the same happens in Malta: aspects of adverse sentiment or negative post-memory are blocked or hidden so as to present a welcoming narrative which hides the hurt, disappointment and at times anger, that are felt by a portion of the Maltese but which are generally manifested only to other Maltese such as through the support of a political party or a foreign football team. ${ }^{5}$

Another facet which would need to be explored in the context of Malta is the renegotiation of Maltese self-identity among the locals who also become recipients of the narratives expressed by the cultural brokers. Two dominant orientations - scorn and idealisation - are tropes of the tourism imaginary in the exoticism of indigenous communities. Theodossopoulus posits that in his research in the Chagres National Park in Panama, parallel levels of exoticisation, but at the same time diametrically opposed, are manifested. ${ }^{6}$ In this case there is an oscillation between the primitive and the noble savage. The present paper draws similar patterns of parallel but opposing tendencies the welcomers with open arms vis-a-vis the offended but dignified Maltese. This oscillation between hospitable and forgiving (in spite of having been considered primitive and inferior by the coloniser) to resolute and defiant is what gives the Maltese their identity and provides a mechanism to keep their painful national post-memories in check.

Ibid., pp. 276-277.

4 E. Bruner, “The Role of Narrative in Tourism", Berkeley conference, On Voyage: New Directions in Tourism Theory, October 7-8, 2005.

5 C. Xuereb, “Malta’s Post-colonial Identity", Times of Malta, 7 June 2018, at <https://cms.timesofmalta.com/articles/view/maltas-post-colonial-identity.681062>, 10 February 2020; A. Cassar Farrugia, A Postcolonial Discussion on Maltese Identity through an Analysis of Modern and Contemporary Maltese Poetry in English, unpublished Bachelor's dissertation, University of Malta 2013, at <https://www. um.edu.mt/library/oar/handle/123456789/7651>, 10 February 2020.

6 D. Theodossopoulos, "Scorn or Idealization? Tourism Imaginaries, Exoticization and Ambivalence in Emberá Indigenous Tourism”, in N.B. Salazar, N.H.H. Graburn (eds.), Tourism Imaginaries: Anthropological Approaches, New York 2016, p. 57. 


\section{FROM COLONY TO SOVEREIGNTY}

The long history of Malta as a colony starts with the first moment when humans set foot on this archipelago. Rarely in the Maltese national memory can it be said that Malta had enjoyed some form of tangible autonomy before 1964. The last in the long series of colonial dominations took effect with the Treaty of Paris of 1814, when the Maltese archipelago was gobbled up by the British war machine and integrated into their steadily expanding colonial empire.

It was in 1964 that Malta finally achieved its political independence from Britain and became a sovereign state. However, up to the present day, contacts between the two countries have persevered in various forms. Following its independence, and until 1979, Malta continued to rent a military base to Britain, while the NATO (North Atlantic Treaty Organisation) allies were also on Maltese soil through the presence of HAFMED (Headquarters Allied Forces Mediterranean). During that time, many British continued to roam around Malta, some as military personnel, others as business people and yet others as tourists on holiday or to revive reminisces of the days when they had served or lived on the island in colonial times. One may arguably describe the 1964-1979 period as a time of relative colonialism mainly due to the fact that the Maltese were still significantly dependent on funds being received under the Defence Agreement (Agreement on Mutual Defence and Assistance between the Government of Malta and that of the UK) for the use of military facilities, providing a financial agreement of $£ 50$ million in grants and loans. ${ }^{7}$

The military agreement meant that various locations on the island were 'out of bounds' for the Maltese and all those visitors and tourists who did not form part of the military structures. The Defence Agreement stipulated that: land (including service establishments and service installations) held, occupied or used, and any right in or over land exercisable by the British authorities or any authorised service organisation shall not be subject to compulsory acquisition, expropriation or extinguishment. ${ }^{8}$

The Maltese were thus precluded from attractive areas, such as the Tigne Beach Lido at Qui-si-Sana in the bustling town of Sliema, as these places were reserved for the exclusive enjoyment of British military personnel and their visiting families and friends. This meant that many Maltese felt strangers in their own land but they could do little to alleviate the situation if they wished to have the funds to support and develop their newly acquired sovereignty and become truly independent - a paradox if there ever was one!

During this transitional period, a postcolonial flavour continued to manifest itself also through the nascent tourism industry which was highly dependent on UK tour

H. Frendo, Malta's Quest for Independence, Malta 1989, pp. 257-259.

8 United Nations, "United Kingdom of Great Britain and Northern Ireland and Malta: Agreement on mutual defence and assistance (with annex). Signed at Malta on 21 September 1964," no. 8518, in Treaty Series: Treaties and International Agreements Registered or Filed and Recorded with the Secretariat of the United Nations, vol. 588, New York 1968, p. 86, at <https://treaties.un.org/doc/Publication/ UNTS/Volume\%20588/v588.pdf>, 12 July 2014. 
operators and their British clients. One author in the 1960s observed that the main street, Kingsway, is flanked for much of its length by small undistinguished shops, many of them offering supplies and souvenirs aimed at sailors and tourists. ${ }^{9}$ The main thoroughfare of the capital city of independent Malta continued to bear the colonial name of 'Kingsway' indicating that there was still a lack of political will to shed the British legacy, with Malta's agenda during the first decade of Maltese sovereignty set on preserving the links and ties existing with the UK, these being considered too important to mishandle.

Keeping the British happy included the types of food offered at most of the local restaurants. The dishes were predominantly suited to British taste through the widespread availability of the English Breakfast, meat and 'two veg', followed by pudding, and even more significantly through the all-inclusive menus catering for the 'Brits.' Other food items available included chips, cottage pie, turkey, corned beef and butter. Catering for a British market meant that the ex-coloniser, now tourist, needed to feel 'at home,' and this is exactly what the Maltese restaurateurs and hoteliers strived to do. ${ }^{10}$

The seaside localities of Bugibba and Qawra became flooded with English-style pubs for British tourists; similar pubs also sprouted all over Sliema and St Julian's along the much sought-after promenades, as also within four- and five-star hotels. With the end of the military base in 1979, successive Maltese governments have striven to diversify the economy and shed off as many as possible of the reminders of colonial life. Among other efforts this exercise has also focussed on the expansion and development of a more attractive touristic product in an effort to make Malta convenient to a globalised tourism market. ${ }^{11}$ Yet, though Malta has been a member of the European Union since 2004, one has to acknowledge that the British presence continues to be somewhat prominent in the archipelago. Rather than related to military or political encroachments - directly linked to the realities of a colonial status or a postcolonial residue this presence is today associated with Malta's tourism industry.

Statistics for the 2014-2016 period at once reveal the sustained presence of UK visitors to Malta. Thus in 2014, there were 487,714 tourists, in 2015 this number rose to 525,996 , while in 2016 , it again increased to $559,987 . .^{12}$ These quantities add up to $27.34 \%, 29.5 \%$ and $28.5 \%$ respectively of the total tourist arrivals for each of these three years. The numbers in 2017 were relatively similar to the previous year at 560,893 , which meant a $0.2 \%$ increase ${ }^{13}$; even though small, it was still an increase. The British seem to continue to want to go to Malta, and the Maltese continue to do their best to welcome them. And the trend has not subsided. ${ }^{14}$

\footnotetext{
9 C. Owen, The Maltese Islands, London 1969, p. 15.

10 J. Schofield, E. Morrissey, Strait Street - Malta's 'Red-Light district' Revealed, Malta 2013.

11 G. Cassar, “Tourism”, in M. Briguglio, M. Brown (eds.), Sociology of the Maltese Islands, Malta 2016, pp. 241-256.

12 Malta Tourism Authority, Tourism in Malta: Facts \& Figures 2016, Malta 2016, p. 6.

13 Malta Tourism Authority, Tourism in Malta: Facts \& Figures 2017, Malta 2017, p. 6.

14 See for example, Malta Tourism Authority, Tourism in Malta: Facts \& Figures 2018, Malta 2018, p. 6.
} 
One hotelier, Joe Preca of the Preluna Hotel (which has been operating in Malta since 1969), observed that British tourists go to Malta because they feel at home there. On the other hand, other tourists, such as the Germans, visit Malta and though they like what they see their eventual repeat visits do not compare to those of the British tourist. ${ }^{15}$

Questions that come to mind regarding the still relatively strong British presence and that feeling of closeness for some - after more than fifty years of political independence, would include: To what extent, if any, has the Maltese relationship with their ex-colonisers changed; or has it evolved? How has this host-guest relationship affected the Maltese national identity? These questions need to be examined in the context of a post-memory dichotomy, following the perspective proposed by Marianne Hirsch, Postmemory describes the relationship of the second generation to powerful, often traumatic, experiences that preceded their births but that were nevertheless transmitted to them so deeply as to seem to constitute memories in their own right. ${ }^{16}$

\section{PERTINENT GEOGRAPHICAL AND HISTORICAL CONSIDERATIONS}

The Maltese archipelago lies in the middle of the Mediterranean Sea. This geographical position has donned these islands with a significance that amply exceeds their physical size at 316 sq. km. Malta, the principal island, possesses a natural harbour that ranks amongst the finest in the Mediterranean and has been a central attribute throughout its history. ${ }^{17}$ Due to Malta's strategic position and its optimal port, every emerging power in the region has eyed the archipelago and considered it wise to possess it. This longing has produced a tall list of dominators among which the: Phoenicians, Carthaginians, Romans, Byzantines, Arabs, Normans, Angevins, Aragonese, Knight Hospitallers, French and British. Each one of these colonisers left an imprint on the Maltese and their land, which in one way or another continues to be manifested to this day in the food, the language, values and beliefs, traditions, as well as in the thoughts and practices of the people of Malta. ${ }^{18}$ One author has observed that the colonisers were indeed affected by colonial possession because: The foreign colonies or possessions of a nation are like the mental acquirements of an individual, and are superadded to its character as well as to its political area. ${ }^{19}$ However, one may perhaps extend this observation by adding that it is not only the coloniser that is impacted by its colonies and possessions but also - and arguably to

15 A. Manduca, "Pioneer's Pride: The Preluna's 40 Years", Times of Malta, 26 March 2009, at <https:// www.timesofmalta.com/articles/view/20090326/business/pioneers-pride-the-prelunas-40years. $250410>, 15$ July 2018 .

16 M. Hirsch, “The Generation of Postmemory”, Poetics Today, vol. 29, no. 1 (2008), p. 103.

17 L. Bugeja, "The historical importance of Malta's Grand Harbour”, Times of Malta, 11 August 2013, at <http://www.timesofmalta.com/articles/view/20130811/life-features/The-historical-importanceof-Malta-s-Grand-Harbour.481865>, 15 July 2018.

18 For a general history of Malta's continued domination see: B. Blouet, The Story of Malta, London 1967. This book has eleven editions.

19 A.L. Kip, Psychology of Nations, New York 1902, p. ix. 
a greater extent - the colonised. For, as Greer has underscored, following colonisation: All the new nations faced severe problems, for political independence did not automatically bring them prosperity and happiness... they were seldom free of external influences. They were still bound to... structures developed earlier by the colonial powers. ${ }^{20}$

Malta is a perfect instance of this reality, which led to what one could possibly consider a colonial withdrawal syndrome. Smith has argued that, the new Military Facilities Agreement, which ran for seven years, ensured that Britain's long association with Malta would continue until 1979. [...] That the shadow of colonial influence and responsibility cast so far beyond Malta's achievement of independent status signifies the degree to which vestiges of imperialism persisted after empire. This existed as much in the minds of Britain's former colonial opponents as in the imperial metropole itself. [...] Indeed, the experience of decolonisation in Malta suggests that dependence and independence frequently coexisted, often uncomfortably, at the end of empire. ${ }^{21}$

The long and tortuous colonial legacy was bound to produce among the Maltese memories that are both visible and tangible, and which may be considered as pleasurable, ambivalent or traumatic. The outcome is neither homogenous nor straightforward. Some Maltese continue to feel an attachment to their country's colonial past, while others may not really feel too bothered about what their country went through and would prefer to look forward and move on. At the other end of the spectrum we may find those that shun the memory and would prefer to put it behind them, denigrating it in the process or who may seek some form of retribution for deeds conflicted on their family members or compatriots Whatever the internal sentiment, however, the vast majority of the Maltese are very much aware that Malta needs to be attractive as a tourist destination. Therefore, it is also essential to continue to entice the British to visit their ex-colony, now not as occupiers but as tourists or guests. Along the years, efforts to achieve this objective have been quite visible in tourist-related literature aimed at the British market. Post-memory in this paper, and as defined by Hirsch earlier, is not bound to just the traumatic experience but, in the case of Malta, collective memory takes on a variegated hue which may arguably be due to the 'love-neutral-hate' continuum. Politically, many would speak of 'Malta tal-Maltin' (translating to: Malta belongs to the Maltese) but economically, the tune is rather different and goes by the Maltese adage 'Malta qatt ma rrifutat qamb' (literal translation: Malta never refused grain - or rather, Malta does not shun what it requires).

\section{LURING EX-COLONIALISTS TURNED TOURISTS - TRAVEL TEXTS AND NARRATIVES}

The discursive study presented hereunder focuses on a distinct tension surrounding tourist practices viewed through the contrasting travel representations of the play

20 T.H. Greer, A Brief History of the Western World, $5^{\text {th }}$ edition, San Diego, CA 1987, pp. 536-537.

21 S.C. Smith, "Dependence and Independence: Malta and the End of Empire", Journal of Maltese Histo$r y$, no. 1 (2008), p. 47. 
between the past and the present. The narrative is aimed at the foreigner, and most especially at the British visitor/tourist since it is written in English. Intertwined in the text is a mix of nostalgia and reality, mildly indicative of an attempt at bridging eras; that is, linking what the colony was like to what the actual sovereign state is today. This is demonstrative of what post-memory has come to signify for the Maltese, a nation that has learnt through time the expediency of adapting to realities and circumstances, a people who are highly pragmatic in much of what they do and a society that looks at what can be salvaged rather than shirking something outright because it harbours undesirable connotations. Resilience has become central in an island that has few resources other than the abilities and ingeniousness of its own people, and this pliability supersedes much of the post-memory reactions and residues pertaining to Malta's colonial past that may otherwise affect negatively the island's future. Indeed, Malta has striven to convert its military role into one fostering peace and exchange, and the vehicle that has been adopted and adapted to achieve this is the tourism industry. All postindependence Maltese governments have looked at ways how to rebrand the nation with the colonial past being transformed into an asset that enhances the attractiveness of the destination especially among the British tourists. ${ }^{22}$

In this article, travel discourse will be taken to signify a social practice, which constitutes and conditions in its representation of power structures. ${ }^{23} \mathrm{~A}$ study of texts prepared by promoters of Malta as a destination, especially for English speaking tourists, written from the 1960s through to the present millennium, brings forth a revealing discourse. Following Beverley Ann Simmons who carried out a similar analysis on popular women's magazines in Australia, a contemporary travel discourse is comprised of four discursive elements which are: privilege, desire and longing, sightseeing, and fanciful play. ${ }^{24}$ The discourse is aimed at attracting, moving and persuading the reader, in this case the British/English-speaking tourist, and the choice of words constitute a compelling read that aims at warming the prospective visitor into a comfortable feeling towards the destination.

\section{PRIVILEGE}

The strategy of conveying the message that the tourist is an esteemed visitor, fortunate to be coming to Malta, is the line adopted by the DK Eyewitness Top 10 Travel Guide in the following excerpt: The tiny Maltese archipelago, floating on the cusp of Europe and

22 M. Avellino Stewart, G. Cassar, "Branding a Nation-state After Half a Century of Independence: The Case of Malta", in L. White (ed.), Commercial Nationalism and Tourism: Selling the National Story, Bristol 2017, pp. 138-148.

23 B.A. Simmons, "Saying the Same Old Things - A Contemporary Travel Discourse and the Popular Magazine Text”, in M. Hall, H. Tucker (eds.), Tourism and Postcolonialism: Contested Discourses, Identities and Representations, New York 2014, p. 43. Cf. also, M. Foucault, The Archaeology of Knowledge, transl. by S. Smith, London 1972; R. Wodak, Disorders of Discourse, London 1996. 
Africa, has been coveted and invaded throughout its history. The Knights of St John (later of Malta) bequeathed palaces, fortresses and the glorious golden capital Valletta, while the British left red telephone boxes, iced buns and a predilection for tea. It was the islands' earliest settlers who left the most spectacular legacy: the extraordinary megalithic temples, unparalleled elsewhere in the world. Malta, the largest island, has the most cosmopolitan resorts and the edge in cultural treasures, while sleepy Gozo and tiny Comino offer unspoilt countryside and a gentler pace. ${ }^{25}$

The narrative in the guidebook uses discourse that aims at creating a tourist-other relationship through the privileged lens. It builds up the expectation that the tourist - the British tourist - is travelling to an elite and unique destination, and it infers that $s / h e$ should feel privileged in being able to visit the ex-colony. To intensify the lure factor, this narrative highlights the presence of familiar items, such as the red telephone boxes and the iced buns washed down by a cup of tea - all well-recognisable and dear to the British tourist. The destination is given a privileged status mostly because it can establish superiority through its products which have that British/Western vibe. The element of privilege is also identified through the notion that tourists are already aware of the historical and geographical places indicated and that they will be in a position of dominance through the possession of prior knowledge once they visit the sites. After all, many British are 'coming back' to what was once their colony, and the Maltese have no problem with welcoming their ex-colonisers, who are now their guests and dominators no more.

In the 1960s, the discourse was somewhat different, though it too was based on the element of privilege. It conveyed the message that Malta was the best choice for the right visitors, that is, for the British ex-armed services personnel and others who had worked on the island in various positions. Malta was the place to return to for those who, for example, had served on the island during World War Two and now wished to bring over the wife and children to see the war ravages on this mostly-bombed place during the war, visit the stations where they had served and perhaps had been wounded or had lost a friend or colleague. Besides, for British pensioners Malta would be an ideal place to retire to, with winter being much milder and summer much brighter and hot by UK weather standards. Added advantages included the attractive prices which were much lower than those in Italy, northern France and Spain - thus one's money stretched further as it was not pilfered through the harrowing exchange rate; Malta used the sterling at that time. ${ }^{26}$

\section{DESIRE AND LONGING}

Simmons argues that desire and longing are fostered in tourists by using three dominant strategies: (i) through seeking out pleasurable, hedonistic or escapist experiences; (ii) by longing for a past; and, (iii) through a yearning for a Colonial or Western

25 M.A. Gallagher, DK Eyewitness Top 10 Travel Guide: Malta \& Gozo, London 2007, p. 6.

26 S. O'Callaghan, Malta - A Handbook to the Island, $2^{\text {nd }}$ edit., Nairobi ca. 1965. 
influence. ${ }^{27}$ British tourists travelling to the Maltese islands could fulfil their wishes to their heart's delight on all three counts. Through the colourful description in the $D K$ Eyewitness travel guide featured above, the British tourist is invited - enticed - to visit sleepy Gozo and tiny Comino; destinations that take one back to a slow-paced rural and remote past, and where, most importantly and significantly, the contact between themselves and their local hosts is of a more personal nature in the form of a face-toface encounter. The narrative aims to convey to British travellers an exciting expectation; that of experiencing an authentic back-region where a benign domestic existence is eked out and alludes to a sanitised past deprived of the burdens of colonial domination. After all, throughout the British period, Gozo was much less in the colonial limelight than Malta, due to the much reduced British presence.

Desire and longing is targeted in guidebooks because tourism is also prompted by what the heart yearns for and seeks to satisfy. Thus, Frommer's Malta \& Gozo day by day entices the visitors: The Maltese Islands bask in the heart of the Mediterranean Sea and their $200 \mathrm{~km}$ of craggy coastline contain fine beaches, an abundance of opportunities to take to the water and some glorious coastal walks. The coastline has witnessed 7,000 years of often dramatic history and inland you'll discover outstanding sights that include megalithic temples, baroque cities and palaces built by the Knights of St John. A tiny archipelago, this devoutly Catholic nation has for centuries constructed incredible cathedrals and churches... no visit to Malta is ever complete without spending time sampling the country's cheeses, meats and breads, or mulling over a glass or two of local wine..$^{28}$

The writer projects an idyllic destination which should satisfy those who seek to discover Malta's long and rich history, the natural landscape, welcoming sea, architectural variations and culinary delights. A marketing narrative at its best.

At the same time, to touch the British hearts, the author informs these tourists that they could take a ride on what she termed as Malta's grand old buses. At the time the public transport that served all the destinations on the Maltese islands consisted of painted yellow buses, custom build on classic British chassis from companies such as Leyland, Ford, and Bedford, and dated back to the 1950s through to the 1970s. This would surely entice many to take at least one, often boneshaking trip. ${ }^{29}$

\section{SIGHTSEEING}

Tourists are generally associated with sightseeing and expect to experience all that a destination has to offer. Malta undoubtedly has its charms and these are predictably presented in an attractive and flowery language to entice the prospective visitor. Thus, an example from Cadogan Guides describing the northern town of Mellieha: Mellieta is a craggy and picturesque hilltop town with bewitching cave dwellings and houses that cling

\footnotetext{
27 B.A. Simmons, “Saying...”, p. 46.

28 L.A. Rose, Frommer's Malta and Gozo Day by Day, Chichester 2009, p. 3.

29

Ibid., p. 4.
} 
like limpets to the rock face. It has a comparatively modern street plan, with none of the haphazard charm of the southwest, but Mellieha has its own different and more affluent appeal. [...] and was not finally resettled until the 1840s under the safety of the British umbrella. ${ }^{30}$

Travel guides find ways to include the British imprint. It may be argued that they could not miss 164 years and more of British presence, but at the same time little can be detected of the negativity that post-memory would be assumed to harbour in the Maltese. Travel books are promoted, marketed and sold; no one seems to disapprove of the narrative.

In another guidebook, Valletta is the idyllic subject for the sightseeing visitor: Valletta, a glorious city of golden stone, straddles a narrow promontory flanked on either side by magnificent natural harbours. Built for the Knights after the Great Siege of 1565 and named after their victorious Grand Master, Jean Parisot de la Vallette, this fortress city is contained behind a massive ring of impenetrable walls and bastions. Within the walls, the Renaissance streets unfold in an elegant grid. Valletta's heart is broad Triq Ir-Repubblika, Republic Street, lined with princely palaces and dominated by the spectacular Co-Cathedral of St John. From here, side streets flanked by crumbling palazzi slope steeply down to the harbours. Time, neglect and the terrible bombardment of World War II have all taken their toll on this miniature capital, and yet its cobbled streets remain hauntingly redolent of the era of the Knights. Still dreaming of the past, the somnolent city shuts down at nightfall. ${ }^{31}$

Of all the senses, sightseeing is presented as if it were the best means by which to savour or unveil a place. ${ }^{32}$ It is argued that tourists consume places through the 'tourist gaze' which establishes superiority over the 'Other, ${ }^{33}$ further arguing that to some extent self-discovery has been lost in modern tourism. ${ }^{34}$

Research has revealed that the British mature tourist, possibly an ex-coloniser, negotiates images of self, cultural and national identity by visiting places and spaces in Malta, which prima facie may be considered by many as simply another attraction to visit, but digging deeper would reveal that particular places hold hidden meanings for such a visitor. ${ }^{35}$ The narrative in the last quoted excerpt does not miss mentioning the terrible bombardment of World War II,' which is undoubtedly a strongly appealing theme linked to the period of the fortress-colony and which arouses nostalgia, sentiment and a sense of pride, especially in the veteran British visitor as also in many older Maltese indeed, a classical postmodern reality.

30 S. Gaul, Malta, Gozo and Comino, London 2007, p. 180.

31 M.A. Gallagher, DK Eyewitness..., p. 60.

32 B.A. Simmons, “Saying..., p. 47.

33 J. Urry, The Tourist Gaze: Leisure and Travel in Contemporary Societies, London - New Delhi 1990.

34 Ibid. See also C. Rojek, J. Urry, (eds.), Touring Cultures: Transformations of Travel and Theory, London -New York 1997.

35 M. Avellino, The Maltese Gift... 


\section{FANCIFUL PLAY}

It can be argued that tourism is a phenomenon that is concerned with the leisured society at play. ${ }^{36}$ Graburn further emphasised this element by calling it a special kind of play or game. ${ }^{37}$ In line with Simmons, the present authors concur that 'fanciful play' is a fourth discursive element and can be identified in the sample of travel guides being examined as a narrative that draws the three discursive elements of privilege, desire and sightseeing together, to transform the controlled mass tourist into an autonomous traveller. ${ }^{38}$ The travellers' fantasy is drawn from the colonial discourses as they are displaced into a fantastical power game where they are all-knowing, expert explorers, by way of their elite position in the global world. In the travel guide discourses which were highlighted in this article, the harsh reality of oppression and subjugation by the colonial masters and their lackeys, are mitigated or pushed aside, as if they have never existed. Instead, the former coloniser, now tourist, is regaled by fanciful words such as those uttered by Sir Walter Scott when he referred to Valletta as a city built by gentlemen for gentlemen - an idiom that smacks of privilege, as colonial class and social relations are subsumed within the anonymity of the collective, while the doctored imagery presenting a sanitised and distorted past is consciously offered to the British tourist - all in the course of good marketing and tourism promotion. This is the form of post-memory that has been adopted by Malta's tourism industry where hard feelings provoked by its long colonial past are somewhat played down while enhancing that which is pleasant and enticing.

\section{COLONIAL DISCOURSE IN A POST-MEMORY DICHOTOMY}

Making foreigners feel welcome is an inculcated strategy that has been evolving and experiencing refinement since the 1960s. Many Maltese believe that any foreigner who comes to Malta for a number of days on holiday is bound to be of some benefit to the local economy and consequently, directly or indirectly, to them. While tourists may consider themselves a special group, this does not exclude them from needing the locals and thus they feel constrained to seek their support. They are, after all, visitors to a foreign land. It is widely believed that the Maltese locals generally view tourists with a (high) degree of awe, and foster a sense of respect towards them; if not also a hint of servitude. It is common to hear comments among the locals in the vein that 'everything is / should be done for the benefit of the tourist.' A sizable number of the Maltese tend to miss the fact that their land belongs to them and that the visitors are foreigners in

36 P.L. Pearce, The Social Psychology of Tourist Behaviour, Oxford 1982.

37 N.H.H. Graburn, "The Anthropology of Tourism," Annals of Tourism Research, vol. 10 (1983), pp. 9-33.

38 B.A. Simmons, “Saying...”, p. 48. 
their country. Thus, the foreigner becomes the guest who takes over, influences, and impinges upon the local culture, the native habits and the vernacular. Many locals tend to consider themselves privileged to be able to serve the tourists and go out of their way to provide them with what they need and what they prefer. To them tourists are tourists, no matter whether these are from Britain or from other countries.

While hospitality is a Maltese trait, and welcoming foreigners is traditionally a local characteristic, at the same time this attitude also hints to a neo-colonial predisposition. Many still consider the British as a 'special' group of people; and having English as an official language together with the native Maltese, strengthens this feeling further. Arguably, more than a century and a half of British colonial domination has left its mark on the Maltese, and this has been carried forward to post-independence - a substantial prevalence of UK tourists to the tune of about 30 per cent of Malta's tourism market.

Undoubtedly, the Maltese nation has been negotiating a post-memory dialogue since its independence. Many among those who were employed by the British colonial entities, or their relatives, still feel a measure of nostalgia for those times. They speak of the 'good times', a secure employment, a UK pension as well as the numerous affable English officers and their families stationed in Malta for whom they worked. They give the impression of a shared life - whatever this may mean. They speak of the difficult years of World War Two and how the British defended the island fortress of Malta their Malta. They reminisce about how the locals were participants, shoulder to shoulder with the British, in the Island's defence. Many served with the armed forces not least as soldiers and sailors of the British Empire.

Another group of locals would beg to differ, rebutting that the war years, heroic though these may have been, were nonetheless a result of Malta being a British colony and naval base - thus participation was more a matter of constraint then of conviction. They consider the colonisers as exploiters, as dominators and as tyrants. They mention the strict laws which the British imposed on the local population. Of the numerous constitutions that were granted to the locals, few allowed enough leeway for Maltese politicians to administer their land and their fellow countrymen. The Anglophobes would point to the restricted military zones and other areas which were out-of-bounds to the locals, and the repulsive feeling of being strangers in their own country.

The post-memory dichotomy is very real and palpable to this day. Some would go so far as to object to the George Cross featured on the Maltese flag. ${ }^{39}$ This was the decoration given by King George VI to all the Maltese in 1942 honouring them in recognition for acts of the greatest heroism or for most conspicuous courage in circumstance of extreme danger. This is nostalgia turned to aversion as some would consider the George Cross on the flag as a vestige of colonial servitude in a sovereign state which has since 1974 declared itself a republic.

Aversion can be traced to political realities in Malta. In the 1970s and early 80s, many called the British 'il-barrani' (the foreigner), a term coined by Dom Mintoff,

39 "Campaign wants George Cross replaced by the Maltese Cross on the flag", Times of Malta, 24 September 2013, at <https://www.timesofmalta.com/articles/view/20130924/local/campaign-wantsgeorge-cross-replaced-by-the-maltese-cross-on-the-flag.487479>, 24 July 2018. 
leader of the Malta Labour Party and Prime Minister of Malta at the time. Mintoff transmitted to his followers a sense of anger towards the ex-colonisers. He wished to see them go from Malta and the island rid itself of their presence. ${ }^{40}$ This was a postmemory reality coming from those who had experienced the British in their worse state of imposition - putting down the riots instigated by the Maltese Labourites, imposing a constitution which controlled all aspects of life, reducing the Maltese political parties to a state of uselessness and a sense of inability to act. Force was also meted out on whoever showed resistance and the indelible mark left on that generation has since been carried forward to this day. Paradoxically, the same people who harboured such antagonism wooed Brits to come to Malta as tourists at a time when the economy needed a boost and more diversification. ${ }^{41}$

During the twentieth century, the Maltese came face to face with the extreme realities of British supremacy causing the locals to harbour a sentiment of detestation that was gradually but consistently passed on from one generation to the next - through history book accounts, political commemorations and collective memory. In these events the coloniser used various forms of constraint - moral, military and political - to control and suppress the Maltese. In such circumstances, animosity was hard to restrain and this sentiment became a 'dark' post-memory legacy. Topping these clashes was the one that broke on 7 June 1919 when the Maltese congregated in the capital city, Valletta, to support their political leaders while these were discussing a self-government constitution which they were determined to request from their colonisers. During this same manifestation, many Maltese also came together in their hundreds to demonstrate in favour of a decent wage, the lowering of the price of bread - their staple food - and to express their anger at how they were being treated in their own country by the 'foreigner' (Maltese: il-barrani). The British authorities sent in troops who were ordered to fire on the crowd - an ill-fated decision that resulted in the killing or wounding of a number of Maltese. These victims became heroes and martyrs of the nation and are commemorated to this day in an official ceremony that evokes the Sette Giugno Riots, as these disturbances are known. Proclaimed as one of Malta's National Feasts, the spirit of national pride and a subtle sense of vexation vibrates in the air during the annual commemoration, while a monument erected in front of the former British Governor's palace (now the seat of the President of the Republic of Malta) presents a permanent reminder to the people of Malta of this bloody and dark event. ${ }^{42}$

40 See for example, Kissinger Cables, "MINTOFF BEGINS TO SHOW HIS HAND”, 15 October 1976, 16:22 (Friday), at <https://www.independent.com.mt/uploads/filebrowser/MINTOFF \%20BEGINS\%20TO\%20SHOW\%20HIS\%20HAND-15\%20Oct\%201976_1.pdf>, 10 February 2020.

41 M.K. Oglethorpe, “Tourism in Malta: A Crisis of Dependence”, Leisure Studies, vol. 3, no. 2 (1984), pp. 147-161.

42 Some books on the subject are: P. Bartolo, X'kien gara sew fis-Sette Giugno, Malta 2019; H. Frendo (ed.), The Sette Giugno - In Maltese History 1919-2019, Malta 2019; A. Cutajar, Remembering Sette Giugno 1919, G. Cassar (ed.), Malta 2019; R. Mangion (ed.), Sette Giugno Centinarju, Malta 2019. 
Another 'blood and iron' clash took place on 28 April 1958 as a reaction to a general strike planned by the Mintoff-led Malta Labour Party and his ally the General Workers' Union. In the widespread rioting, many were wounded by the police following British orders. Up to this day this event continues to be considered by those who were there and many of their descendants as an action against the arrogance of the British imperial government, and the feeling of resentment has not subsided. ${ }^{43}$

Colonial post-memory does however have a more mellow side as the Maltese transport themselves back to the cruel years of World War Two when bombs were showered on the population day and night. Memories of the suffering, the hunger, the desperate defence, the tragic losses, but also the already indicated feeling of camaraderie between the Maltese and the British, have lingered on and passed down through the descendants. An amicable sentiment from those days has been moulded into a 'bond' with the British coloniser-now-tourist. A large number of books continue to commemorate and celebrate the Island's heroism, determination, loyalty and fraternal interactions with the British overlords from those epic years. ${ }^{44}$ Today's Maltese children still hear the narratives and accounts that have come down from the 1940s, orally transmitted from grandparents to parents to nephews and nieces thus sustaining a tangible post-memory.

\section{CONCLUSION}

This paper sought to understand the present-day relationship between the British tourists and Maltese nationals and to what extent post-memory of the colonial period is transmitted through the cultural brokers.

Indeed, post-memory is a challenging element to deal with. To this day some Maltese still feel hurt by the past that has lingered on in many aspects of Maltese life. British tourists, on the other hand, continue to feel attracted to Malta, with many considering it as a sort of 'coming home' when they revisit the George Cross Island, which fills them with nostalgia. ${ }^{45}$ Numerous Maltese also continue to feel close to the British and among the many manifestations of this attraction they support English local and national football teams, visit Britain regularly for holidays or to study in UK educational institutions, as also for specialised medical care. Besides, the Maltese educational system has continued to draw inspiration from the British system, with advisors and

43 See for example, "GWU monument to 'soldiers of steel' of 1958 riots", Times of Malta, 28 April 2015, at <https://timesofmalta.com/articles/view/gwu-monument-to-soldiers-of-steel-of-1958riots.565964>, 12 February 2020. See also, A. Sant, 28 ta’ APRIL 1958 - Hobż u Helsien, Malta 1988.

44 Some books on the subject are: E. Bradford, Siege: Malta 1940-1943, Barnsley 1985; D. Austin, Churchill and Malta's War 1939-1943, New York 2010; S. Thomas, Greetings from Malta, World War II, Tasmania 1996.

45 See for example, George Cross Island Association, at <http://www.georgecrossisland.org.uk/>, 25 July 2018. 
leading educators regularly sought from the former mother country. Malta also continues to form part of the British Commonwealth as the political, medical, educational and social relationships are close and active.

Arguably, while the vestiges of colonialism continue to permeate contemporary Maltese realties, many locals do not appear to be excessively inconvenienced. It may take many decades still for the neo-colonial residues to subside and the effects of postmemory to stabilise among the Maltese. However, up to this day one may argue that many Maltese are still, in their own ways, quite 'British' and strategically use this narrative to continue attracting British tourists to the Islands, with success.

\section{BIBLIOGRAPHY}

Austin D., Churchill and Malta's War 1939-1943, New York 2010.

Avellino M., The Maltese Gift: Tourist Encounters with the Self and the Other in Later Life, unpublished Ph.D. thesis, London Metropolitan University, 2016, at <http://ethos.bl.uk/OrderDetails.do?uin=uk.bl.ethos.694191>.

Avellino Stewart M., Cassar G., "Branding a Nation-state after Half a Century of Independence: The Case of Malta", in L. White (ed.), Commercial Nationalism and Tourism: Selling the National Story, Bristol 2017.

Bartolo P., X'kien gara sew fis-Sette Giugno, Malta 2019.

Blouet B., The Story of Malta, London 1967.

Bradford E., Siege: Malta 1940-1943, Barnsley 1985.

Bruner E., "The Role of Narrative in Tourism", Berkeley conference, On Voyage: New Directions in Tourism Theory, October 7-8, 2005.

Bugeja L., "The Historical Importance of Malta's Grand Harbour", Times of Malta, 11 August 2013, at <http://www.timesofmalta.com/articles/view/20130811/life-features/The-histo rical-importance-of-Malta-s-Grand-Harbour.481865>.

"Campaign wants George Cross replaced by the Maltese Cross on the flag". Times of Malta 24 September 2013, at <https://www.timesofmalta.com/articles/view/20130924/local/ campaign-wants-george-cross-replaced-by-the-maltese-cross-on-the-flag.487479>.

Cassar G., "Tourism", in M. Briguglio, M. Brown (eds.), Sociology of the Maltese Islands, Malta 2016.

Cassar Farrugia A., A Postcolonial Discussion on Maltese Identity through an Analysis of Modern and Contemporary Maltese Poetry in English, unpublished Bachelor's dissertation, University of Malta 2013, at <https://www.um.edu.mt/library/oar/handle/123456789/7651>.

Cutajar A., Remembering Sette Giugno 1919, G. Cassar (ed.), Malta 2019.

Foucault M., The Archaeology of Knowledge, transl. by A.M. Sheridan Smith, London 1972.

Frendo H., Malta's Quest for Independence, Malta 1989.

Frendo H. (ed.), The Sette Giugno - In Maltese History 1919-2019, Malta 2019.

Gallagher M.-A., DK Eyewitness Top 10 Travel Guide: Malta \& Gozo, London 2007.

Gaul S., Malta, Gozo and Comino, London 2007.

George Cross Island Association, at <http://www.georgecrossisland.org.uk/>. 
Graburn N.H.H., “The Anthropology of Tourism”, Annals of Tourism Research, vol. 10 (1983), <https://doi.org/10.1016/0160-7383(83)90113-5>.

Greer T.H., A Brief History of the Western World, $5^{\text {th }}$ edition, San Diego, CA 1987.

Hirsch M., “The Generation of Post-memory”, Poetics Today, vol. 29, no. 1 (Spring 2008), <https://doi.org/10.1215/03335372-2007-019>.

Jezewski M.A., Sotnik P., The Rehabilitation Service Provider as Culture Broker: Providing Culturally Competent Services to Foreign Born Persons. Buffalo, NY 2001.

Kip A.L. Psychology of Nations, New York 1902.

Malta Tourism Authority, Tourism in Malta: Facts \& Figures 2016, Malta 2016.

Malta Tourism Authority, Tourism in Malta: Facts \& Figures 2017, Malta 2017.

Malta Tourism Authority, Tourism in Malta: Facts \& Figures 2018, Malta 2018.

Manduca A., "Pioneer's Pride: The Preluna's 40 Years”, Times of Malta, 26 March 2009, at <https://www.timesofmalta.com/articles/view/20090326/business/pioneers-pride-theprelunas-40-years.250410>.

Mangion R. (ed.), Sette Giugno Centinarju, Malta 2019.

Oglethorpe M.K., “Tourism in Malta: A Crisis of Dependence”, Leisure Studies, vol. 3, no. 2 (1984,), <https://doi.org/10.1080/02614368400390131>.

O'Callaghan S., Malta - A Handbook to the Island, $2^{\text {nd }}$ edition, Nairobi ca. 1965.

Owen Ch., The Maltese Islands, London 1969.

Pearce P.L., The Social Psychology of Tourist Behaviour, Oxford 1982, <https://doi.org/10.1016/ B978-0-08-025794-5.50007-8>.

Rojek C., Urry J. (eds.), Touring Cultures: Transformations of Travel and Theory, London -New York 1997.

Rose L.A., Frommer's Malta and Gozo Day by Day, Chichester 2009.

Sant A., 28 ta' APRIL 1958 - Hobż u Helsien, Malta 1988.

Schofield J., Morrissey E., Strait Street-Malta's 'Red-Light district'Revealed, Malta 2013.

Simmons B.A., "Saying the Same Old Things", in M. Hall, H. Tucker (eds.), Tourism and Postcolonialism: Contested Discourses, Identities and Representations, New York 2014.

Smith S.C., "Dependence and Independence: Malta and the End of Empire", Journal of Maltese History, no. 1 (2008).

Theodossopoulus D., “Scorn or Idealization?”, in N.B. Salazar, N.H.H. Graburn (eds.), Tourism Imaginaries: Anthropological Approaches, New York 2014.

Thomas S., Greetings from Malta, World War II, Tasmania 1996.

United Kingdom of Great Britain and Northern Ireland and Malta, 1967, "Agreement on Mutual Defence and Assistance", 21 September 1964, no. 8518, in Treaty Series: Treaties and International Agreements Registered or Filed and Recorded with the Secretariat of the United Nations, Vol. 588, New York 1968, at <https://treaties.un.org/doc/Publication/UNTS/ Volume\%20588/v588.pdf>.

Urry J., The Tourist Gaze: Leisure and Travel in Contemporary Societies, London - New Delhi 1990.

Wodak R., Disorders of Discourse, London 1996.

Xuereb Ch., "Malta's Post-colonial Identity", Times of Malta, 7 June 2018, at $<$ https://cms. timesofmalta.com/articles/view/maltas-post-colonial-identity.681062>. 
Prof. George Cassar - Associate Professor in the Institute for Tourism, Travel and Culture (ITTC) of the University of Malta. He is a historical sociologist whose main research interests include the History and Sociology of Education; the Pedagogy of Heritage, History and Social Studies; the History of History Teaching; the Study of the Order of St. John (SMOM); the History and Culture of Malta; Heritage and Culture; Cultural Tourism; and, the Culture and Sociology of Food. He is the author or editor of numerous books and academic journals, and has contributed many papers in journals and chapters in books related to his areas of interest. He is very much involved in EU funded projects where he has served in a number of roles including that of project manager in the lead partner role. He was for three years a member of the Research Coordinating Committee of the 'Valletta 2018' - Valletta European Capital of Culture 2018 - representing the University of Malta and also headed the V18 Secretariat on campus. Between 2017 and 2020 he sat on the Board of Directors of the Malta Tourism Authority.

Dr Marie Avellino - Director of the Institute for Tourism, Travel and Culture at the University of Malta. Her research interests include Social Anthropology, Cultural Heritage, Tourism and Older Adults and Seniors, Cultural Identities, Intercultural Competencies for Management and Visitor Experience Management. Her EU-Funded Projects experience includes 2012-2014 Lead Researcher in the Grundtvig Lifelong Learning Programme, entitled Socialising Tourism, SoTo and the 2013-2015 - Project Manager for Grundtvig Lifelong Learning Programme, entitled Heritage Interpretation for Senior Audiences, HISA and the more recent involvement such as Project Manager for two 2018-2021 Erasmus + Key Action 2 Strategic Partnerships with the Project Title 'Boosting blue Entrepreneurs' competences toward an environmental care ecosystem' (BLUESPROUT) and the 2019-2021 Skills for promotion, valorisation, exploitation, mediation and interpretation of European Cultural Heritage (EUHeritage). 